\title{
Decision Support System for Employee Candidate Selection using AHP and PM Methods
}

\author{
Soleman \\ Faculty of Computer Science, \\ Information System Technology \\ Borobudur University Jakarta, Indonesia
}

\begin{abstract}
PT. Prima Grafika is a digital printing company that is looking for the best prospective employees. Based on research and observations that have been made, the company only uses administrative data in selecting prospective employees. Processing a lot of data and documents with the same applicant's name slowing down the data processing and exceeding the time limit has been determined to get the best employees. The solution to this problem is by making a web-based system in recruitment, a decision support system combined with Analytic Hierarchy Process (AHP) method as a weighting to conduct priority criteria analysis by pairwise comparisons between two criterion so that all criteria are covered, and the Profile Matching (PM) method as a ranking. This study uses three methods of testing, namely, Black Box Testing system tested by 60 respondents who can be accepted by the company; User Acceptance Testing (UAT) obtained from 10 respondents with an ideal score of 900 produced an actual score of 779 or $86.1 \%$, in total this whole system is acceptable; and Delone and McLean Model Test Results obtained from 10 respondents with an ideal score of 850 produced an actual score of 726 or $\mathbf{8 5 . 7 \%}$ which is very good. With the results of ranking: A001 - Cantika Dewi $=$ 4.12, A004-Arif Yulkianto $=3.98$, A002 Eprriadi = 3,913, A003-Rika Novriani = 3,467.
\end{abstract}

Keywords-Prospective employees; decision support systems; Analytic Hierarchy Process (AHP); profile matching

\section{INTRODUCTION}

Large companies and the development of a company cannot be separated from the role of employees. PT. Prima Grafika is a full service Digital Printing company, including Repro, Design, Computer to Plate, Computer to Film, Digital Press, Digital Offset, and Photobook. This company grew into a large enough company by opening several branches so that a selection of prospective new employees was made to occupy the required position. New employee selection aims to get the best employees that can work well.

Observations have been made for the employee selection process at PT. Prima Grafika. Data was obtained that the employee selection process was only carried out with administrative processes such as diplomas and certificates of work experience possessed by applicants. In addition, this process was difficult because of the large amount of applicant data that had to be processed; many applicant files had the same name and were vulnerable to being swapped.

The solution that will be applied by researchers in the selection of new employees at the PT Prima Grafika is to create a web-based application in recruitment by implementing the decision support system of the Analytic Hierarchy Process (AHP) combination method in weighting, conducting priority analysis of criterion with paired comparison methods between the two criterion and Profile Matching (PM) as the calculation of the final result (ranking).

This process will save time and money for the company because the process will be automatic and the result can be read based on the rank. The employees with the highest score are the best employee who will get a position that fits the company's criteria. Decision support systems expand the ability of decision makers to process data or information using a computer system that processes data into information for decision-making on semi-structured specific issues like in this company.

A similar study conducted in 2016 by Moedjiono, et al. using AHP and PM methods but had different goals. Their research was conducted to support decisions in order to improve the effectiveness of sending the best employees, increasing customer satisfaction from 3 Aspects of 7 criteria especially Intellectual Aspects and Work Attitude. While in this research a decision support system will be applied using a combination of Analytic Hierarchy Process and Profile matching methods, with three aspects (Aspects of Nature and Behavior, Intellectual Aspect, Administrative Aspect) which are divided into 11 sub aspects or criteria, namely, Work Motivation, Appearance, Accuracy, Speed, Intelligence, Language Mastery, Problem Solving, Domicile, Diploma, Work Experience and Age.

\section{THEORETICAL BACKGROUND}

\section{A. Decision Support System}

According to Pratiwy (2016) understanding of decision support systems proposed by McLeod which states that a decision support system is a system of producing information aimed at a problem that must be created by managers, decision support system is an information system intended to help management in solving problems they faced.

\section{B. Study Overview}

Research on decision support systems using the Analytical Hierarchy Process (AHP) approach and the Profile Matching (PM) method or those relating to employee selection have been conducted by several people including.

Decision support system used in the selection of candidates or employees with a comparison of two methods in 
the calculation process, that the Analytical Hierarchy Process (AHP) is better / complex than the Multi Factor Evaluation Process (MFEP), determined by four criteria: interview (0.558), writing test $(0.122)$, psychological test $(0.263)$, and health test (0.057), that is, candidates who meet the requirements are accepted by 2 candidates and 4 candidates with values of 8.42 and 8.23 (for MFEP) and 0.277 and 0.342 (for AHP), respectively; the results are consistent standards[1]. Decision support system that is used can help to rank the top down employees who have the best performance and so it can be in the decision making to choose alternative employee mutations 40\%, 60\% [2]. Decision support system used to determine the best employee can be proven that consistency below $<0.100$ with IR is 0.5 results that have been obtained are criteria such as the following: Disciplinary criteria: $\mathrm{CR}=0.95$, Responsibility criteria: $\mathrm{CR}=0.58$, Skills : $\mathrm{CR}=\mathrm{O}, 95$, and Cooperation $\mathrm{CR}=0.95$ [3]. Decision support system with a combination of research methods can be used as a decision maker in order to increase the effectiveness of sending the best candidates / employees, and increase customer satisfaction, and reduce costs and increase the company's gross operating margin. The final result of software quality according to respondents is Good with the percentage of respondents at $83.87 \%$ [4]. decision support system in the comparison between Analytical Hierarchy Process (AHP) and Simple Additive Weighting (SAW) methods, is used to find out the accuracy of each method in determining employee employee performance appraisal, namely the Highest Score \{(SAW: 0.871) (AHP) : 0.368), Lowest score (SAW: 0.686) (AHP: 0.110), average final score (SAW: 0.767) (AHP: 0.2), Total from the final score accumulation (SAW: 3.834) (AHP: 1) Accuracy AHP results are more accurate than SAW [5]. The decision support system for the Promethee method. Promethee Method is one method of determining the order or priority in MCDM (Multi Criterion Decisin Making) or decision making [6]. Decision Support Systems can support all who support decision making to help improve and facilitate the decision making process. The results of this study will produce a ranking ranking of employees and this application can help the results of decisions in choosing alternative employees who excel [7]. Decision Support System with the MFEP method in determining high achieving students gives subjective and intuitive consideration in giving weight to each criterion [8]. Decision support system uses the PM method in determining employee achievement with aspects of the criteria: disciplined achievement, integrity, organizational commitment, leadership teamwork, work performance and service oriented [9]. The results of his research the method used for performance assessment it is very difficult to state where the method is better to use than others because it depends on the type and business size; classifies many criteria decision making techniques (MCDM) such as TOPSIS,FTOPSIS, AHP and FAHP, fuzzy multistage, cascaded fuzzy, Neuro-Fuzzy (NF) and Fuzzy evaluation is type-2. So the right technique must be selected based on the existing application [10]. Research with an AHP-based metalearning algorithm is proposed to identify the guided classification algorithm that is most suitable for developing cynical decision support systems. The results of the ten publicly available medical datasets show that the support vector machine has the highest potential to perform well on various medical data sets [11]. This study is on the adoption of social media in employee recruitment and selection by testing the Unified Theory of Acceptance and Use of Technology (UTAUT), the results obtained from modeling the partial least square path, using cross-sectional data collected from 224 recruiters, showing that the hypothesis The core of UTAUT is supported, namely the positive impact of performance expectations [12]. The research that the backfilling algorithm does not provide better scheduling if there is the same type of rental and must be conjugative. By using AHP (Analytic Hierarchy Process) as a decision maker in the backfilling algorithm increases the performance of the refilling algorithm by scheduling more rent amounts and minimizing the rejection of leases using AHP [13]. This study applies the Methods for Order Preference with Ideal Solution Equality (TOPSIS) to determine vocational schools. Criteria for Heart Decision Criteria Requires C1, C2 C3 Facilities, Quality Accreditation, C4 HR Students, C5 Fees [14].

This research applies the system Decision Support performance appraisal employee for employee selection achievers. In profile matching, good or bad identification of groups of employees is done. The employees inside the group was measured using some assessment criteria namely aspects of discipline, collaboration and work performance [15]; research assessment of employee performance. Conduct an assessment in giving awards for outstanding employees including using a support system a decision in helping a solution problem. The method used in giving awards for outstanding employees namely the profile method matching. Criteria or aspects use on the award decision support system. These outstanding civil servants (PNS) are discipline, integrity, organizational commitment, leadership, cooperation, work performance and service oriented [16]. Decision support system used shows that the consistency ratio (CR) of the five criteria is $\mathrm{CR}=0.0976$ which shows that consistency in all criteria has more weight with the amount of accuracy: $43 \%$ when compared to other criteria with teaching methods $(30 \%)$ teaching quality (16\%), initiative (7\%), skills and personal (4\%) [17]. Employee performance appraisal using the profile matching method that is able to select employees with achievements with determined aspects, namely, aspects of work targets and behavioral aspects and seven sub criteria [18]. Decision support systems are applied in the selection of ERP systems using software applications that are being developed. This software application makes it easy to apply the AHP process to the selection of ERP packages and will allow updates and improvements to the model [19]. Research with decision support systems is using AHP and TOPSIS methods algorithm as an effective tool for supporting machines selection decision. In this study, weights Different criteria are calculated using the AHP method and to choose the most preferred machine one of the well-known MCDM methods namely the TOPSIS method has used and checked back using Microsoft Office Superior [20].

\section{Analytic Hierarchy Process (AHP) Method}

The AHP method was developed by Thomas L. Saaty, a mathematician. This method is a framework for making decisions effectively, simplify, speeding up complex 
decisions. Give numerical value to subjective considerations about the importance of each variable and synthesize these various considerations to determine which variable has the highest priority and act to influence the outcome of the situation.

The stages in using the Analytic Hierarchy Process (AHP) Method in solving problems there are some basic principles that must be understood, namely:

Create a hierarchy. Complex systems can be understood by breaking them down into supporting criteria, constructing criteria in a hierarchical manner, and combining them, such as the hierarchical structure in Fig. 1.

1) Evaluation of criteria and alternatives is done by comparison of various issues, scale 9 is the best scale for expressing opinions. The values and definitions of qualitative opinions from the Saaty comparison scale can be measured using the analysis in Table I.

2) Determine priorities (synthesis of priority). For each criterion and alternative used, pairwise comparison is needed. The values of all criteria and alternative comparisons can be adjusted according to predetermined judgments to produce weights and priorities.

Establish priorities and prepare pairwise comparisons that compare all criteria for each hierarchy if the operating subsystems have $\mathrm{n}$ operating criteria namely $\mathrm{A}_{1}, \mathrm{~A}_{2}, \ldots, \mathrm{A} n$ then the results of the comparison of each operating criteria will form a matrix A size $\mathrm{n} \times \mathrm{n}$ in Table II as follows:

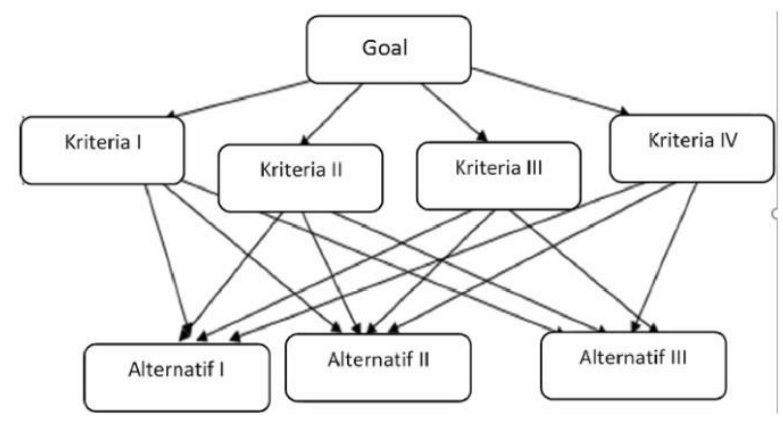

Fig. 1. Hierarchy Structure of AHP

TABLE. I. PAIRWISE COMPARISON SCALE

\begin{tabular}{|l|l|}
\hline Scale of Importance & Information \\
\hline 1 & Both criteria has the same influence \\
\hline 3 & $\begin{array}{l}\text { Assessment is in favor of one of the criteria than } \\
\text { their pair }\end{array}$ \\
\hline 5 & $\begin{array}{l}\text { Assessment is very favoring one of the criteria } \\
\text { compared to their pair }\end{array}$ \\
\hline 7 & $\begin{array}{l}\text { One criterion is very influential and its dominance } \\
\text { is real }\end{array}$ \\
\hline 9 & $\begin{array}{l}\text { Evidence that one of the criteria is more important } \\
\text { than the partner at the highest level of confidence. }\end{array}$ \\
\hline $2,4,6,8$ & $\begin{array}{l}\text { The value is given if there is doubt between two } \\
\text { adjacent values }\end{array}$ \\
\hline Reverse & $\begin{array}{l}\text { If criterion i has one of the numbers above } \\
\text { compared to criterion j, then } \mathrm{j} \text { has the inverse value } \\
\text { when compared to criterion } \mathrm{i}\end{array}$ \\
\hline
\end{tabular}

TABLE. II. PAIRWISE COMPARISON MATRIX [5]

\begin{tabular}{|l|l|l|l|l|}
\hline & $\mathrm{A}_{1}$ & $\mathrm{~A}_{2}$ & $\cdots$ & $\mathrm{A}_{\mathrm{n}}$ \\
\hline $\mathrm{A}_{1}$ & $\mathrm{a}_{11}$ & $\mathrm{a}_{12}$ & $\cdots$ & $\mathrm{a}_{1 \mathrm{n}}$ \\
\hline $\mathrm{A}_{2}$ & $\mathrm{a}_{21}$ & $\mathrm{a}_{12}$ & $\cdots$ & $\mathrm{a}_{2 \mathrm{n}}$ \\
\hline$\vdots$ & $\vdots$ & $\vdots$ & $\ddots$ & $\vdots$ \\
\hline $\mathrm{A}_{\mathrm{n}}$ & $\mathrm{an}_{1}$ & $\mathrm{a}_{\mathrm{n} 2}$ & $\cdots$ & $\mathrm{a}_{\mathrm{mn}}$ \\
\hline
\end{tabular}

With a pairwise comparison matrix, normalization is performed using the following steps:

3) The weight of each column $\mathrm{j}$ is summed, the total column values are denoted by $S_{i j}$

$S_{i j}=\sum_{i=1}^{n} a_{i j}$

4) The value of each column is divided by the total value of the column. The results of that division are symbolized by $\mathrm{V}_{\mathrm{ij} \text {. }}$

$\mathrm{V}_{\mathrm{ij}}=\frac{a_{i j}}{S_{i j}}$

$I j=1,2,3, \ldots, \mathrm{n}$

Furthermore, by calculating the relative priority vectors of each criterion by averaging the normalized weights with the ith row. The i-th priority criteria is dsymbolized by $\mathrm{Pi}$.

$P_{i}=\sum_{i=1}^{n} \frac{Q i}{n}$

5) Logical consistency. Consistency has two meanings namely similar objects can be grouped according to uniformity and relevance, and relationships between objects based on certain criteria

Assessment with a matrix often has small changes in the value of aij which affect the maximum eigenvalue. Whereas the maximum eigen value deviation determines the size of consistency. Indicators of consistency are measured through the consistency index as follows:

$C I=\frac{\lambda_{m a k s}-n}{n-1}$

AHP measures all consistency assessments using the consistency ratio (CR) formulated:

$C R=\frac{C I}{R 1}$

A certain level of consistency is needed in determining priorities to get the best results. CR value $\leq 0.100$ is consistent if it was not, it needs to be revised. The limit of consistency determined by Saaty, measured using the Consistency Ratio (CR), which is a comparison of the consistency index with a random generator value (RI).

$\mathrm{N}$ is the order of matrix $\mathrm{n}$ with the number 11 based on the order of the matrix, whereas RI is the Random Index for $0<\mathrm{n}$ $<11$. This value depends on the order matrix $n$. To see the percentage of ratio consistency from pairwise comparison in the AHP process is in Table III (derived from Saaty's book) as follows: 
TABLE. III. RI VALUE RANDOM INDEX [6]

\begin{tabular}{|l|l|l|l|l|l|l|}
\hline $\mathrm{N}$ & 1 & 2 & 3 & 4 & 5 & 6 \\
\hline $\mathrm{RI}$ & 0.00 & 0.00 & 0.58 & 0.90 & 1.12 & 1.24 \\
\hline $\mathrm{N}$ & & 7 & 8 & 9 & 10 & 11 \\
\hline $\mathrm{RI}$ & 1.32 & 1.41 & 1.45 & 1.49 & 1.51 \\
\hline
\end{tabular}

\section{Profile Matching Method}

According by [21] profile matching is a situation where the client will get the expected results. In the profile matching process, there will be a comparison process between individual competencies into standard competencies, in this case an ideal applicant profile so that competency differences can be known (also called gaps). The smaller the gap produced, the greater the weight value. Applicants who have a large weight value means have a greater chance to be accepted in the company, seen in Table IV as follows:

Gap = Attribute Value - Target Value

Calculation and Grouping of Core Factors and Secondary Factors After determining the weight of the gap values for all aspects in the same way, each aspect is further divided into two groups, namely, the core factor (main factor) and secondary factor (supporting factors). Calculation of core factors and secondary factors can be shown in equation [7].

1) Core Factor Calculation

$N C F=\frac{\sum N C(i, s, p, x)}{\sum I C}$

Information:

NCF : The average value of the core factor

NC (i, s, p, x) : Total number of core factor values

(administration, competence, interview, psychological test)

IC : Number of core factor items Calculation of

2) Secondary Factor

$N S F=\frac{\sum N C(i, s, p, x)}{\sum I S}$

Information:

NSF : average value of secondary factor

NS $(i, s, p, x) \quad$ : Total number of secondary

(administration, competence,

interview, psychological test)

IS : Number of secondary factor items

3) Calculation of Total Value

$\mathrm{N}(\mathrm{I}, \mathrm{S}, \mathrm{P}, \mathrm{X})=(\mathrm{X}) \% \cdot \mathrm{NCF}(\mathrm{I}, \mathrm{S}, \mathrm{P}, \mathrm{X})+(\mathrm{X}) \% \cdot \mathrm{NSF}(\mathrm{I}, \mathrm{S}, \mathrm{P}, \mathrm{X})$

Information:

NCF $(\mathrm{i}, \mathrm{s}, \mathrm{p}, \mathrm{x}) \quad$ : Average value of core factor

(administration, competence,

interview, psychological test)
NSF (i,s,p,x) : Average value of secondary factor

(administration, competence,

interview, psychological test)

$\mathrm{N}(\mathrm{i}, \mathrm{s}, \mathrm{p}, \mathrm{x})$ : Total value of the aspect

(administration, competence,

interview, psychological test)

(X)\% : The percent value inputted

4) Calculation of Ranking Determination

The final results of candidates submitted to fill a certain position in the company.

Ranking $=(\mathrm{x}) \% . \mathrm{Ni}+(\mathrm{x}) \% . \mathrm{Ns}=(\mathrm{x}) \% . \mathrm{Np}+(\mathrm{x}) \% . \mathrm{Nx}$

Information :

$\mathrm{Ni}$ : Administration value

Ns: Competency score

NP: The value of the interview

Nx: Psychological values

(X)\%: The percent value inputted

\section{E. Employee Candidate Selection}

Employee selection is the first effort a company must make to find employees that are in line with the company's expectations based on ability and in accordance with the position it occupies.

The definition of employee selection according to some experts is:

1) The decision making process chooses someone to fill a work position based on the suitability of individual characteristics with the needs of the job position [8].

2) The process of obtaining and using information about job applicants to determine who should be accepted to occupy short-term and long-term positions [9].

3) The process of identifying and selecting people from a group of applicants who are the most suitable or most qualified for a particular position or position [10].

TABLE. IV. GaP Weight VALUe

\begin{tabular}{|l|l|l|}
\hline Gap & Weight Value & Information \\
\hline 0 & 5 & No gap (Competency matched with need) \\
\hline 1 & 4,5 & Individual competency is 1 level more \\
\hline-1 & 4 & Individual competency is 1 level less \\
\hline 2 & 3,5 & Individual competency is 2 level more \\
\hline-2 & 3 & Individual competency is 2 level less \\
\hline 3 & 2,5 & Individual competency is 3 level more \\
\hline-3 & 2 & Individual competency is 3 level less \\
\hline 4 & 1,5 & Individual competency is 4 level more \\
\hline-4 & 1 & Individual competency is 4 level less \\
\hline
\end{tabular}




\section{SySTEMS DESIGN AND APPLICATION}

\section{A. Method of Analysis}

Analysis of the data of this study uses quantitative data which is a form of research method used to examine a particular population or sample, collecting data using research instruments with the aim to test the hypotheses that have been set. After the data is collected, the data is transcribed by applying the Analytic Hierarchy Process (AHP) as a determinant of the weight of the criteria, where each evaluation criterion is compared with each other and the Profile Matching (PM) method as a method for determining alternative final values. Reports generated by this system are ranking reports of all alternatives (applicants) that have been sorted by the largest alternative value. The next step is to create an application with the PHP and MySQL programming languages as the database. Prospective employees received are Prospective employees who occupy the highest ranking position of the number of applicants available, based on the number of company needs for the selected prospective employees.

\section{B. Technique of Analysis}

The analysis technique used in this study uses the Object Oriented Analysis (OOA) approach or object-oriented analysis with UML. The analysis process is carried out on the results of the stages of data collection by interviewing, observing and studying the literature to get a specification of the system requirements to be developed. In the analysis process that will be carried out are:

1) Analysis of Data and Information obtained from interviews, observations, and literature studies.

2) Analysis of Functional, non-functional and user needs. Functional requirements modeling to describe the system functions and users involved as well as what functions will be obtained by each user is modeled using a use case diagram.

3) In this research the decision support system approach technique uses a combination of Analytic Hierarchy Process (AHP) and Profile Matching (PM) methods.

Use Case diagram in Fig. 2 is a system design process that will be made in selecting prospective employees. As an actor or actor the assessment in the system design is carried out by recruitment staff who carry out the selection process. Use Case diagram illustrates that recruitment staff can $\log$ in to process alternative data, criteria, criteria weights, Profiles, Calculations, Print and logout from the system As shown in Fig. 2 as follows:

\section{Design Technique}

This sequence diagram illustrates the dynamic collaboration between objects that shows a series of messages between actors (Staff Recruitment) and the system. Following is the Sequence diagram of a prospective employee selection decision support system as shown in Fig. 3 as follows:

Class diagram of the decision support system for prospective employee selection, in this study describes the structure and description of the class and the relationship between classes, as shown in the following Fig. 4:

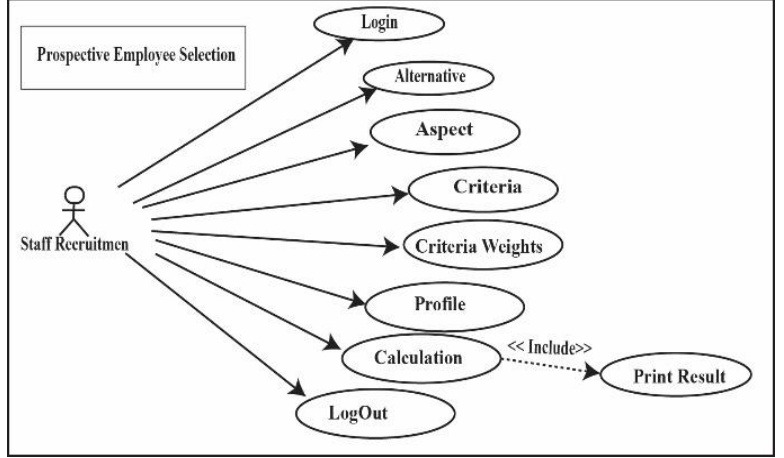

Fig. 2. Use Case Diagram of Decision Support System.

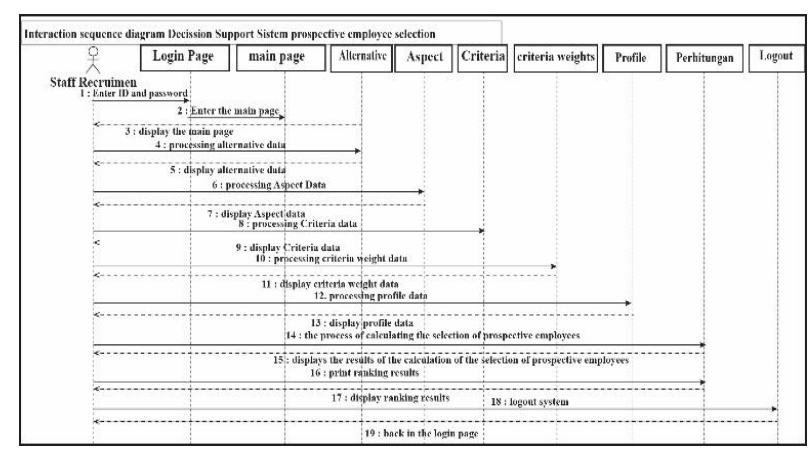

Fig. 3. Sequence Diagram of Prospective Employee Selection.

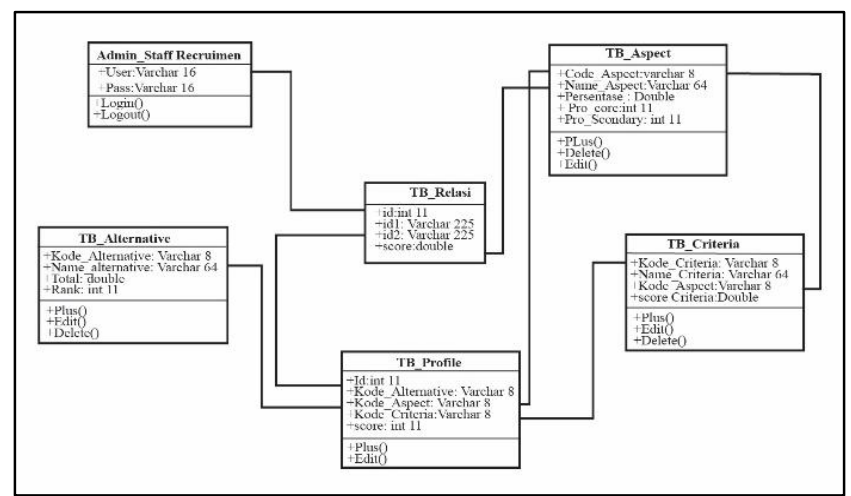

Fig. 4. Class Diagram of Prospective Employee Selection.

\section{RESULT AND DisCUSSION}

\section{A. Data Collection}

The results of interviews with HRD PT. Prima Grafika establishes 3 Aspects and 11 Sub-Aspects (criteria) and four sample applicants data for 2018 that can be used as validation calculations in the decision support system. The following are the prospective employee criteria determined by the HRD PT. Prima Grafika can be seen in Table V as follows:

There are two types of Sub aspects (criteria), namely:

1) Core Factor, the most important or prominent criteria (competencies) or most needed by an assessment with a value of $60 \%$.

2) Secondary Factor (supporting factors), which are items other than those in the core factor with a value of $40 \%$. 


\section{B. AHP Weighting Process}

Determining the value of the pairwise matrix comparison is done by the AHP method. Compare input data between criteria in a paired matrix using the AHP importance intensity scale. This process is carried out to determine the value of the ratio of consistency of comparison (CR), where the $\mathrm{CR}$ condition $<0.1$. The first aspect of the nature and behavior aspects based on work, appearance, accuracy, speed, subaspects can be seen in Table VI as follows:

The Second Aspect of Intellectual Aspect based on Sub Aspect of Intelligence, Handling Problems, Language Mastery, can be seen in Table VII as follows:

The Third Aspect of Administrative Aspects based on Sub Aspects of work motivation, Appearance, Accuracy, Speed can be seen in Table VIII as follows:

Example Explanation: Aspect Comparison Matrix The properties and behavior in Table VI. are evaluated and added to each column to get the following results: Column AI01 = 1 $+0.5+0.333+0.25=2.083$. The next step is to divide the numbers in Table VI. by the number of each column, so that a normalization matrix is formed. AI01 column AI01 line divided by the number of AI01 columns $=1 / 2,083=0.48$, and the average AI01 line $=(0.48+0.5217391+0.461538+$ $0.4 / 4)=0.465819$.

After that the Consistency Measure Phase = the same two array matrix of the same number of rows as A101 code and the same number of columns with the weight value $=1,2,3,4$ (in Table VI) + average weight (in Table IX) divided weights A101 The results can be seen in Table IX, X and XI as follows:

TABLE. V. ASPECT AND CRITERION (SUB ASPECT)

\begin{tabular}{|l|l|l|l|}
\hline Aspect & Code & Criterion (sub aspect) & Factor \\
\hline \multirow{4}{*}{$\begin{array}{l}\text { Nature and } \\
\text { Behavior aspect }\end{array}$} & AI01 & Work's motivation (MK) & Core \\
\cline { 2 - 4 } & AI02 & Appearance (PNP) & Secondary \\
\cline { 2 - 4 } & AI03 & Accuracy (KTL) & Secondary \\
\cline { 2 - 4 } & AI04 & Speed (KCP) & Secondary \\
\hline \multirow{4}{*}{$\begin{array}{l}\text { Intellectual } \\
\text { aspect }\end{array}$} & AII01 & Intelligence (KCS) & Core \\
\cline { 2 - 4 } & AlI02 & Problem solving (PMS) & Secondary \\
\cline { 2 - 4 } & AII03 & Language mastery (PBS) & Secondary \\
\hline \multirow{4}{*}{$\begin{array}{l}\text { Administrative } \\
\text { Aspect }\end{array}$} & AIII01 & Education/Diploma (IJZ) & Core \\
\cline { 2 - 4 } & AIII02 & Domicile (DMS) & Secondary \\
\cline { 2 - 4 } & AIII03 & Work experience (PKJ) & Secondary \\
\cline { 2 - 4 } & AIII04 & Age(USA) & Secondary \\
\hline
\end{tabular}

TABLE. VI. COMPARISON MATRIX OF ASPECTS OF NATURE AND BEHAVIOR

\begin{tabular}{|l|l|l|l|l|}
\hline Kode & AI01 & AI02 & AI03 & AI04 \\
\hline AI01 & 1 & 2 & 3 & 4 \\
\hline $\mathrm{AI} 02$ & 0.5 & 1 & 2 & 3 \\
\hline $\mathrm{AI} 03$ & 0.333 & 0.5 & 1 & 2 \\
\hline $\mathrm{AI} 04$ & 0.25 & 0.333 & 0.5 & 1 \\
\hline Total & 2.083 & 3.833 & 6.5 & 10 \\
\hline
\end{tabular}

TABLE. VII. MATRIX INTELLIGENCE COMPARISON

\begin{tabular}{|l|l|l|l|}
\hline Kode & AII01 & AII02 & AII03 \\
\hline AII01 & 1 & 5 & 2 \\
\hline AII02 & 0.2 & 1 & 0.2 \\
\hline AII03 & 0.5 & 5 & 1 \\
\hline Total & 1.7 & 11 & 3.2 \\
\hline
\end{tabular}

TABLE. VIII. MATRIX ADMINISTRATIVE COMPARISON

\begin{tabular}{|l|l|l|l|l|}
\hline Kode & AIII01 & AIII02 & AIII03 & AII04 \\
\hline AIII01 & 1 & 9 & 2 & 7 \\
\hline AIII02 & 0.11 & 1 & 0.2 & 1 \\
\hline AIII03 & 0.5 & 5 & 1 & 9 \\
\hline AIII04 & 0.143 & 1 & 0.111 & 1 \\
\hline Total & 1.754 & 16 & 3.311 & 18 \\
\hline
\end{tabular}

TABLE. IX. NORMALIZATION OF ASPECTS OF NATURE AND BEHAVIOR

\begin{tabular}{|l|l|r|r|l|l|c|}
\hline Code & AI01 & AI02 & AI03 & AI04 & weight & CM \\
\hline AI01 & 0.48 & 0.5217391 & 0.461538 & 0.4 & 0.465819 & 4.051335 \\
\hline AI02 & 0.24 & 0.2608696 & 0.307692 & 0.3 & 0.27714 & 4.041634 \\
\hline AI03 & 0.16 & 0.1304348 & 0.153846 & 0.2 & 0.16107 & 4.015971 \\
\hline AI04 & 0.12 & 0.0869565 & 0.076923 & 0.1 & 0.09597 & 4.015218 \\
\hline & & & & & & 16.12416 \\
\hline & & & & & & 4 \\
\hline
\end{tabular}

TABLE. X. NORMALIZATION OF INTELLECTUAL ASPECTS

\begin{tabular}{|l|l|l|l|l|l|}
\hline Kode & AII01 & AII02 & AII03 & Weight & CM \\
\hline AII01 & 0.588 & 0.45 & 0.625 & 0.556 & 3.085 \\
\hline AII02 & 0.118 & 0.09 & 0.063 & 0.090 & 3.014 \\
\hline AII03 & 0.294 & 0.45 & 0.313 & 0.354 & 3.063 \\
\hline & & & & & 9.161726 \\
\hline & & & & & 3 \\
\hline
\end{tabular}

TABLE. XI. NORMALIZATION OF ADMINISTRATIVE ASPECTS

\begin{tabular}{|l|l|l|l|l|l|l|}
\hline Kode & AIII01 & $\begin{array}{l}\text { AIII0 } \\
2\end{array}$ & AIII03 & $\begin{array}{l}\text { AIII0 } \\
4\end{array}$ & Weight & CM \\
\hline $\begin{array}{l}\text { AIII0 } \\
1\end{array}$ & 0.57 & $\begin{array}{l}0.562 \\
5\end{array}$ & $\begin{array}{l}0.60402 \\
7\end{array}$ & 0.389 & $\begin{array}{l}0.46581 \\
9\end{array}$ & $\begin{array}{l}4.05133 \\
5\end{array}$ \\
\hline $\begin{array}{l}\text { AIII0 } \\
2\end{array}$ & $\begin{array}{l}0.06334841 \\
6\end{array}$ & $\begin{array}{l}0.062 \\
5\end{array}$ & $\begin{array}{l}0.06040 \\
3\end{array}$ & 0.056 & 0.27714 & $\begin{array}{l}4.04163 \\
4\end{array}$ \\
\hline $\begin{array}{l}\text { AIII0 } \\
3\end{array}$ & $\begin{array}{l}0.28506787 \\
3\end{array}$ & $\begin{array}{l}0.312 \\
5\end{array}$ & $\begin{array}{l}0.30201 \\
3\end{array}$ & 0.5 & 0.16107 & $\begin{array}{l}4.01597 \\
1\end{array}$ \\
\hline $\begin{array}{l}\text { AIII0 } \\
4\end{array}$ & $\begin{array}{l}0.08144796 \\
4\end{array}$ & $\begin{array}{l}0.062 \\
5\end{array}$ & $\begin{array}{l}0.03355 \\
7\end{array}$ & 0.056 & 0.09597 & $\begin{array}{l}4.01521 \\
8\end{array}$ \\
\hline & & & & & & $\begin{array}{l}16.1241 \\
6\end{array}$ \\
\hline & & & & & & 4 \\
\hline
\end{tabular}


Example remarks in Table IX: The total value with 4 results on the Consistency Measure on the index ratio is 0.90 and the Consistancy Index: $(16.12416 / 4)-4) /(4-1)=0.010$ i.e. as a limit of the consistency measured using the Consistency Ratio (CR). Consistancy Ratio: 0.01, namely, the consistency ratio shows the extent to which the analyst is consistent in giving a value to the comparison matrix. In general, the results of the analysis are considered consistent if they have a CR of $10 \%$.

The Last Stage The result of the weight value based on the AHP calculation is the value of the criterion that has the greatest weight. The criteria that prioritize the results are consistent with the results of Aspect weights and behavioral order of the criteria that have the highest score to the smallest score that can be seen in Tables XII, XIII and XIV as follows:

\section{Determine the Profile Value}

Profile values are alternative values for each criterion (range 1-5). This is the value obtained from the alternative, while the Criteria Weight is the expected value to be sought from the alternative. In this stage the value data of prospective employees will be generated in accordance with existing values in knowledge-based. The first value sought is value according to company norms. In psychological values and interviews on aspects of nature and behavior, intellectual aspects can be seen in Table XV as follows:

Administrative value determined by PT. Prima Grafika can be seen in Tables XVI, XVII, XVIII and XIX as follows:

The abbreviation information from 3 aspects and 11 sub aspects are Work Motivation (WM), Appearance (AP), Accuracy (AC), Speed (SP), Intelligence (IN), Language Mastery (LM), Problem Solving (PS), Diploma (DI), Domicile (DM), Work Experience (WE), Age (AG) can be seen in Table XX as follows:

TABLE. XII. SCORE RESUlt OF WEIGHT ASPECTS OF NATURE AND BEHAVIOUR

\begin{tabular}{|l|l|l|}
\hline Code & Criterion & Score \\
\hline AI01 & Work's motivation & 5 \\
\hline AI02 & Appearance & 3 \\
\hline AI03 & Accuracy & 2 \\
\hline AI04 & Speed & 1 \\
\hline
\end{tabular}

TABLE. XIII. SCORE RESUlt OF INTELLECTUAL ASPECT

\begin{tabular}{|l|l|l|}
\hline Code & Criterion & Score \\
\hline AII01 & Intelligence & 5 \\
\hline AII02 & Problem solving & 1 \\
\hline AII03 & Mastery of language & 3 \\
\hline
\end{tabular}

TABLE. XIV. SCORE RESULt OF WEIGHT ASPECT OF ADMINISTRATIVE

\begin{tabular}{|l|l|l|}
\hline Code & Criterion & Score \\
\hline AIII01 & Education / Diploma & 5 \\
\hline AIII02 & Domicile & 1 \\
\hline AIII03 & Work experience & 3 \\
\hline AIII04 & Age & 1 \\
\hline AIII01 & Education / Diploma & 5 \\
\hline
\end{tabular}

TABLE. XV. PSYCHOLOGICAL TEST AND INTERVIEW SCORE

\begin{tabular}{|l|l|}
\hline Category & Score \\
\hline Very good & 5 \\
\hline Good & 4 \\
\hline Good enough & 3 \\
\hline Enough & 2 \\
\hline Lacking & 1 \\
\hline
\end{tabular}

TABLE. XVI. WEIGHT OF EDUCATION VALUE

\begin{tabular}{|l|l|}
\hline Category & Score \\
\hline S2 & 5 \\
\hline S1 & 4 \\
\hline D3 & 3 \\
\hline High school (SMA) & 2 \\
\hline Junior high (SD-SMP) & 1 \\
\hline
\end{tabular}

TABLE. XVII. WeIGHT OF Domicile VALUE

\begin{tabular}{|l|l|}
\hline Location distance $(\mathrm{Km})$ & Score \\
\hline$\leq 2$ & 5 \\
\hline $3-5$ & 4 \\
\hline $6-7$ & 3 \\
\hline $8-9$ & 2 \\
\hline$\geq 10$ & 1 \\
\hline
\end{tabular}

TABLE. XVIII. WEIGHT OF WORK EXPERIENCE VALUE

\begin{tabular}{|l|l|}
\hline Work experience (years) & Score \\
\hline$>10$ & 5 \\
\hline $5-10$ & 4 \\
\hline $3-4$ & 3 \\
\hline $1-2$ & 2 \\
\hline 0 th & 1 \\
\hline
\end{tabular}

TABLE. XIX. WEIGHT VALUE FOR AGE

\begin{tabular}{|l|l|}
\hline Age & Score \\
\hline $18-20$ th & 5 \\
\hline $21-25$ th & 4 \\
\hline $26-30$ th & 3 \\
\hline $31-35$ th & 2 \\
\hline$>35$ th & 1 \\
\hline
\end{tabular}

TABLE. XX. Alternative Value

\begin{tabular}{|l|l|l|l|l|l|l|l|l|l|l|l|}
\hline \multirow{2}{*}{$\begin{array}{l}\text { KOD } \\
\text { E }\end{array}$} & $\begin{array}{l}\text { W } \\
\text { M }\end{array}$ & $\begin{array}{l}\text { A } \\
\text { P }\end{array}$ & $\begin{array}{l}\text { A } \\
\text { C }\end{array}$ & SP & IN & $\begin{array}{l}\text { L } \\
\text { M }\end{array}$ & PS & $\begin{array}{l}\text { D } \\
\text { I }\end{array}$ & $\begin{array}{l}\text { D } \\
\text { M }\end{array}$ & $\begin{array}{l}\text { W } \\
\text { E }\end{array}$ & $\begin{array}{l}\text { A } \\
\text { G }\end{array}$ \\
\hline A001 & SB & B & B & B & B & CB & B & $\begin{array}{l}\text { S } \\
1\end{array}$ & 6 & 3 & 21 \\
\hline A002 & B & B & B & $\begin{array}{l}\text { C } \\
\text { B }\end{array}$ & $\begin{array}{l}\text { S } \\
\text { B }\end{array}$ & SB & $\begin{array}{l}\text { S } \\
\text { B }\end{array}$ & $\begin{array}{l}\text { S } \\
1\end{array}$ & 6 & 5 & 21 \\
\hline A003 & CB & B & SB & B & B & B & S & S & 6 & 3 & 21 \\
\hline A004 & B & B & B & B & S & B & B & S & 6 & 5 & 24 \\
\hline
\end{tabular}


Profile value is the weight of alternative values from the conversion results of sub criteria evaluation can be seen in Table XXI.

\section{Calculation Process of Profile Matching}

After knowing the results of the Criteria Weighting, the next step is to calculate using Profile Matching. In the calculation process of this study the authors take the example of four prospective employees who will be made simulations for the calculation process, can be seen in Table XXII.

Example Explanation Calculation of the nature and behavior aspects based on the values that have been converted to the weight value of each sub-criterion, the column section is the code Aspect criteria and the row section is an alternative that has been determined by PT. Prima Grafika, can be seen in Tables XXIII, XXIV and XXV.

TABLE. XXI. Profile VAlue

\begin{tabular}{|l|l|l|l|l|l|l|l|l|l|l|l|}
\hline \multirow{2}{*}{$\begin{array}{l}\text { COD } \\
\text { E }\end{array}$} & \multicolumn{9}{|l|}{ Score of sub-criterion } \\
\cline { 2 - 14 } & $\begin{array}{l}\text { W } \\
\text { M }\end{array}$ & $\begin{array}{l}\text { A } \\
\text { P }\end{array}$ & $\begin{array}{l}\text { A } \\
\text { C }\end{array}$ & $\begin{array}{l}\text { S } \\
\text { P }\end{array}$ & $\begin{array}{l}\text { I } \\
\text { N }\end{array}$ & $\begin{array}{l}\text { L } \\
\text { M }\end{array}$ & $\begin{array}{l}\text { P } \\
\text { S }\end{array}$ & $\begin{array}{l}\text { D } \\
\text { I }\end{array}$ & $\begin{array}{l}\text { D } \\
\text { M }\end{array}$ & $\begin{array}{l}\text { W } \\
\text { E }\end{array}$ & $\begin{array}{l}\text { A } \\
\text { G }\end{array}$ \\
\hline A001 & 5 & 4 & 4 & 4 & 4 & 3 & 4 & 4 & 3 & 3 & 4 \\
\hline A002 & 4 & 4 & 4 & 3 & 5 & 5 & 5 & 4 & 3 & 4 & 4 \\
\hline A003 & 3 & 4 & 5 & 4 & 4 & 4 & 5 & 4 & 3 & 3 & 4 \\
\hline A004 & 4 & 4 & 4 & 4 & 5 & 4 & 4 & 4 & 3 & 4 & 4 \\
\hline
\end{tabular}

TABLE. XXII. LIST OF System TeST ALTERNATIVE

\begin{tabular}{|l|l|l|}
\hline No & Kode & Alternatif \\
\hline 1 & A001 & Cantika Dewi \\
\hline 2 & A002 & Eprriadi \\
\hline 3 & A003 & Rika Novriani \\
\hline 4 & A004 & Arif yulkianto \\
\hline
\end{tabular}

TABLE. XXIII. SCORE OF NATURAL AND BEHAVIOUR ASPECT

\begin{tabular}{|l|l|l|l|l|}
\hline Code & AI01 & AI02 & AI03 & AI04 \\
\hline A001 & 5 & 4 & 4 & 4 \\
\hline A002 & 4 & 4 & 4 & 3 \\
\hline A003 & 3 & 4 & 5 & 4 \\
\hline A004 & 4 & 4 & 4 & 4 \\
\hline Criterion value & 5 & 3 & 2 & 1 \\
\hline
\end{tabular}

TABLE. XXIV. SCORE OF INTELLECTUAL ASPECT

\begin{tabular}{|l|l|l|l|}
\hline Kode & AII01 & AII02 & AII03 \\
\hline A001 & 4 & 3 & 4 \\
\hline A002 & 5 & 5 & 5 \\
\hline A003 & 4 & 4 & 5 \\
\hline A004 & 5 & 4 & 4 \\
\hline Criterion value & 5 & 1 & 3 \\
\hline
\end{tabular}

TABLE. XXV. SCORE OF ADMINISTRATIVE ASPECT

\begin{tabular}{|l|l|l|l|l|}
\hline Kode & AIII01 & AIII02 & AIII03 & AIII04 \\
\hline A001 & 4 & 3 & 3 & 4 \\
\hline A002 & 4 & 3 & 4 & 4 \\
\hline A003 & 4 & 3 & 3 & 4 \\
\hline A004 & 4 & 3 & 4 & 4 \\
\hline Criterion value & 5 & 1 & 3 & 1 \\
\hline
\end{tabular}

Examples of calculation information from Table XXVI are in Table XXIII Alternative code A001 with criteria A101 is the difference from code A001 with the criteria value AI01, namely: weight value of 5 with the gap (gap) criterion value 5 $=0$, Code A001 with the value of criterion A102 is the difference from Code A001 with AI02 criteria, namely: weight value 4 with a gap value of criterion value $3=1$, Code A001 with a criterion value A103 is the difference from code A001 with a criterion of AI03 namely: weight value 4 with a gap (gap) value of criterion $2=2$, Code A001 with criteria value A104 is the difference from code A001 with criteria AI04, namely: the weight of the value 4 with the difference (gap) value of criteria $1=3$ as in Tables XXVI, XXVII and XXVIII.

Example calculation from Table XXVIII that is based on the competency difference in Table IV the gap value weighting. The weight values are taken from Tables XXVI, XXVII and XXVIII. The results can be seen in Tables XXIX, XXX and XXXI.

TABLE. XXVI. CALCULATION OF MAPPING THE GAP OF NATURE AND BEHAVIOUR ASPECT

\begin{tabular}{|l|l|l|l|l|}
\hline Kode & AI01 & AI02 & AI03 & AI04 \\
\hline A001 & 0 & 1 & 2 & 3 \\
\hline A002 & -1 & 1 & 2 & 2 \\
\hline A003 & -2 & 1 & 3 & 3 \\
\hline A004 & -1 & 1 & 2 & 3 \\
\hline
\end{tabular}

TABLE. XXVII. CALCULATION OF MAPPING THE GAP OF INTELLIGENCE ASPECT

\begin{tabular}{|l|l|l|l|}
\hline Kode & AII01 & AII02 & AII03 \\
\hline A001 & -1 & 2 & 1 \\
\hline A002 & 0 & 4 & 2 \\
\hline A003 & -1 & 3 & 2 \\
\hline A004 & 0 & 3 & 1 \\
\hline
\end{tabular}

TABLE. XXVIII. CALCUlation OF MaPPING THE GaP AdMinistrative ASPECT

\begin{tabular}{|l|l|l|l|l|}
\hline Kode & AIII01 & AIII02 & AIII03 & AIII04 \\
\hline A001 & 4 & 3 & 3 & 4 \\
\hline A002 & 4 & 3 & 4 & 4 \\
\hline A003 & 4 & 3 & 3 & 4 \\
\hline A004 & 4 & 3 & 4 & 4 \\
\hline Criterion value & 5 & 1 & 3 & 1 \\
\hline
\end{tabular}


TABLE. XXIX. WEIGHTING GAP'S SCORE OF NATURE AND BEHAVIOUR ASPECT

\begin{tabular}{|l|l|l|l|l|}
\hline Kode & AI01 & AI0 & AI03 & AI04 \\
\hline A001 & 5 & 4.5 & 3.5 & 2.5 \\
\hline A002 & 4 & 4.5 & 3.5 & 3.5 \\
\hline A003 & 3 & 4.5 & 2.5 & 2.5 \\
\hline A004 & 4 & 4.5 & 3.5 & 2.5 \\
\hline
\end{tabular}

TABLE. XXX. WEIGHTING GAP'S SCORE OF INTELLIGENCE ASPECT

\begin{tabular}{|l|l|l|l|}
\hline Kode & AII01 & AII02 & AII03 \\
\hline A001 & 4 & 3.5 & 4.5 \\
\hline A002 & 5 & 1.5 & 3.5 \\
\hline A003 & 4 & 2.5 & 3.5 \\
\hline A004 & 5 & 2.5 & 4.5 \\
\hline
\end{tabular}

TABLE. XXXI. WEIGHTING GAP's SCORE OF ADMINISTRATIVE ASPECT

\begin{tabular}{|l|l|l|l|l|}
\hline Kode & AIII01 & AIII02 & AIII03 & AIII04 \\
\hline A001 & 4 & 3.5 & 5 & 2.5 \\
\hline A002 & 4 & 3.5 & 4.5 & 2.5 \\
\hline A003 & 4 & 3.5 & 5 & 2.5 \\
\hline A004 & 4 & 3.5 & 4.5 & 2.5 \\
\hline
\end{tabular}

For example, calculation of Table XXXII in code A001 with criterion A101, criterion A102 Criteria A103, Criteria A104 value from Table XXVIII. The NCF value (core factor value or main factor) known in the AI01 code criteria has the greatest weight and is made the main factor in the Aspects of Nature and Behaviour. NSF value (Secondary Factor Value) is the average value of the Criteria $\mathrm{AI02,} \mathrm{AI03,} \mathrm{AI04}=$ 4.5.3.5.2.5 = 3,500. Total Value $=5,000(\mathrm{NCF}) \times 60 \%$ (core value Main Percentage of company HRD provisions) $+3,500$ (NCF) X $40 \%$ (secondary value Supporting percentage of company HRD provisions) $=4,400$ as Tables XXXII, XXXIII and XXXIV.

TABLE. XXXII. FACTOR CALCULATION OF NATURE AND BEHAVIOUR ASPECT

\begin{tabular}{|l|l|l|l|l|l|l|l|}
\hline Kode & $\begin{array}{l}\text { AI0 } \\
1\end{array}$ & AI02 & AI03 & AI04 & NCF & NSF & Total \\
\hline $\begin{array}{l}\text { A00 } \\
1\end{array}$ & 5 & 4.5 & 3.5 & 2.5 & $\begin{array}{l}5.00 \\
0\end{array}$ & $\begin{array}{l}3.50 \\
0\end{array}$ & $\begin{array}{l}4.40 \\
0\end{array}$ \\
\hline $\begin{array}{l}\text { A00 } \\
2\end{array}$ & 4 & 4.5 & 3.5 & 3.5 & $\begin{array}{l}4.00 \\
0\end{array}$ & $\begin{array}{l}3.83 \\
3\end{array}$ & $\begin{array}{l}3.93 \\
3\end{array}$ \\
\hline $\begin{array}{l}\text { A00 } \\
3\end{array}$ & 3 & 4.5 & 2.5 & 2.5 & $\begin{array}{l}3.00 \\
0\end{array}$ & $\begin{array}{l}3.16 \\
7\end{array}$ & $\begin{array}{l}3.06 \\
7\end{array}$ \\
\hline $\begin{array}{l}\text { A00 } \\
4\end{array}$ & 4 & 4.5 & 3.5 & 2.5 & $\begin{array}{l}4.00 \\
0\end{array}$ & $\begin{array}{l}3.50 \\
0\end{array}$ & $\begin{array}{l}3.80 \\
0\end{array}$ \\
\hline & Core & $\begin{array}{l}\text { Secondar } \\
\mathrm{y}\end{array}$ & $\begin{array}{l}\text { Secondar } \\
\mathrm{y}\end{array}$ & $\begin{array}{l}\text { Secondar } \\
\mathrm{y}\end{array}$ & & & \\
\hline
\end{tabular}

TABLE. XXXIII. FACTOR CALCULATION OF INTELLIGENCE ASPECT

\begin{tabular}{|l|l|l|l|l|l|l|}
\hline Kode & AII01 & AII02 & AII03 & NCF & NSF & Total \\
\hline A001 & 4 & 3.5 & 4.5 & 4.000 & 4.000 & 4.000 \\
\hline A002 & 5 & 1.5 & 3.5 & 5.000 & 2.500 & 4.000 \\
\hline A003 & 4 & 2.5 & 3.5 & 4.000 & 3.000 & 3.600 \\
\hline A004 & 5 & 2.5 & 4.5 & 5.000 & 3.500 & 4.400 \\
\hline & Core & Secondary & Secondary & & & \\
\hline
\end{tabular}

TABLE. XXXIV. FACTOR CALCULATION OF ADMINISTRATIVE ASPECT

\begin{tabular}{|l|l|l|l|l|l|l|}
\hline Kode & AIII01 & AIII02 & AIII03 & NCF & NSF & Total \\
\hline A001 & 4 & 3.5 & 5 & 4.000 & 3.667 & 3.867 \\
\hline A002 & 4 & 3.5 & 4.5 & 4.000 & 3500 & 3.800 \\
\hline A003 & 4 & 3.5 & 5 & 4.000 & 3.667 & 3.867 \\
\hline A004 & 4 & 3.5 & 4.5 & 4.000 & 3.500 & 3.800 \\
\hline & Core & Secondary & Secondary & & & \\
\hline
\end{tabular}

\section{E. Final Calculation}

In this step, all aspect values are calculated according to the percentage applicable to each aspect and calculated based on alternatives and their Subcritical Aspects.

Example of Final Results calculation in Table XXXV in Alternative A001 (Cantika Dewi) Aspects of nature and behaviour with a value of 4.4 (Total NCF and NSF results), intellectual 4 (Total NCF and NSF results), Administrative = 3,867 (NCF and NSF total results) values total $=4.4 \times 40$ (Percentage determined by the company) $+4 \times 30$ (Percentage determined by the company) $+3,867 \times 30 \%$ (Percentage determined by the company) $=4.12$ and the ranking results can be seen in Table XXXV sorted by Weight as the following:

\section{F. Ranking Result}

In ranking, from the results of the final calculation that has been done, then the alternative with the highest value will get the first rank, from the calculation results above, the ranking results obtained in Table XXXVI as follows:

\section{G. Program Implementation}

Making a decision support system in selecting prospective employees is designed in the form of a web-based application. The following is a display of the forms used in the prospective employee selection system.

TABLE. XXXV. FINAL CALCULATION

\begin{tabular}{|l|l|l|l|l|}
\hline \multirow{2}{*}{ Alternative } & \multicolumn{2}{|l|}{ Aspect } & \multirow{2}{*}{$\begin{array}{l}\text { Score } \\
\text { Total }\end{array}$} \\
\cline { 2 - 4 } & $\begin{array}{l}\text { Nature and } \\
\text { Behavior }\end{array}$ & Intelligence & Administrative & 4.12 \\
\hline $\begin{array}{l}\text { A001- } \\
\text { Cantika Dewi }\end{array}$ & 4.4 & 4 & 3.867 & 3.98 \\
\hline A002- Eprriadi & 3.8 & 4.4 & 3.8 & 3.913 \\
\hline $\begin{array}{l}\text { A003- } \\
\text { Rika Novriani }\end{array}$ & 3.933 & 4 & 3.8 & 3.467 \\
\hline $\begin{array}{l}\text { A004-Arif } \\
\text { Yulkianto }\end{array}$ & 3.067 & 3.6 & 3.867 & \\
\hline Percentage & $40 \%$ & $30 \%$ & $30 \%$ & \\
\hline
\end{tabular}

TABLE. XXXVI. RANKING RESULTS

\begin{tabular}{|l|l|l|}
\hline Alternative & Total Score & Rank \\
\hline A001-Cantika Dewi & 4.12 & 1 \\
\hline A004 -Arif Yulkianto & 3.98 & 2 \\
\hline A002- Eprriadi & 3.913 & 3 \\
\hline A003- Rika Novriani & 3.467 & 4 \\
\hline
\end{tabular}


1) Display login page: Is the first appearance of the application when it will enter the system, in this form, the user or user is asked to enter a username and password as seen in Fig. 5.

2) Home page display: The home page is the first display when a user or user logs in to the system as seen in Fig. 6.

3) Alternative page: Alternative pages are pages that contain alternative data or prospective employees to be selected as shown in Fig. 7.

4) Aspect page: An Aspect Page is a page that contains aspect names and percentages that will be used in calculations as seen in Fig. 8.

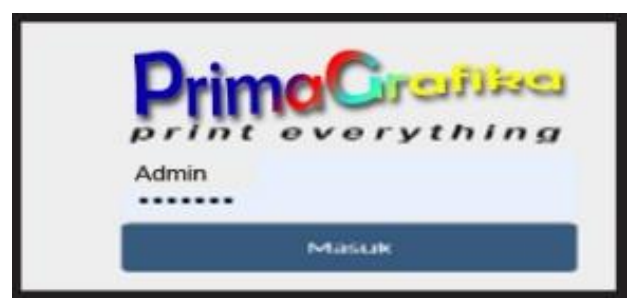

Fig. 5. Login Menu.

alternative Aspect $\mathbf{a}$ Criteria

- Criteria Weight $\mathbf{a}$ Profile

- Calculation

- Password L Logout

Decision Support System for Employee candidate selection Using a combination of Analytic Hierarchy Process methods (AHP) and Profile Matching (PM): Case Study of PT. PrimaGrafika

Fig. 6. Homepage.

$\square$ Alternative $\square$ Aspect $\square$ Criteria $\square$ Criteria Weight $\square$ Profle $\square$ Calculation $\mathbf{a}$ Password $\mathbf{\square}$ Logout

\section{Alternative}

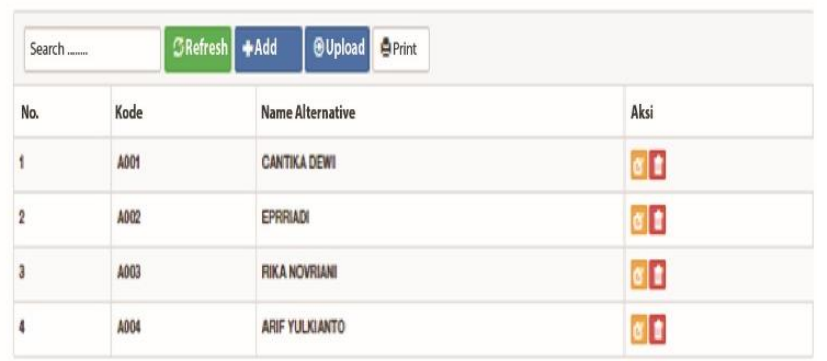

Fig. 7. Alternative Page.

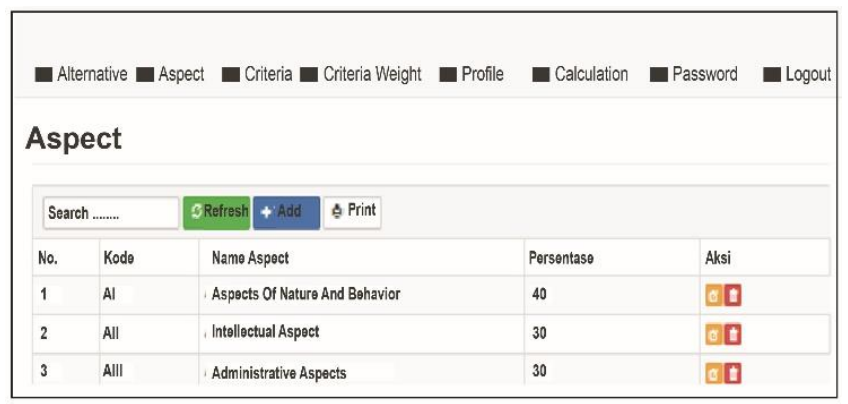

Fig. 8. Aspect Page.
5) Criteria page: Criteria page or also called Sub Aspect is a page that contains criteria that will be used to carry out the employee selection process that can be seen in Fig. 9.

6) Criteria weights page: Criteria Weights Page is the weight that will be used in the process of calculating the selection of prospective employees obtained from the level of importance in the AHP method as seen on Fig. 10.

7) Profile page: Profile pages are alternative values for each criterion (range 1-5). This is the value obtained from the alternative as can be seen on Fig. 11.

8) Calculation page: This Calculation page discusses the calculation process from weighting to the final results in the form of ranking from rank one to the end which shows the quality of prospective employees who will be chosen by the company as seen in Fig. 12.

9) Password page: This application provides a Password page that can be used by Application users to change old passwords with new ones, for the purpose of system security. The page can be seen in Fig. 13.

10)Log out menu: Log out menu is used to signed out from system as seen in Fig. 14.

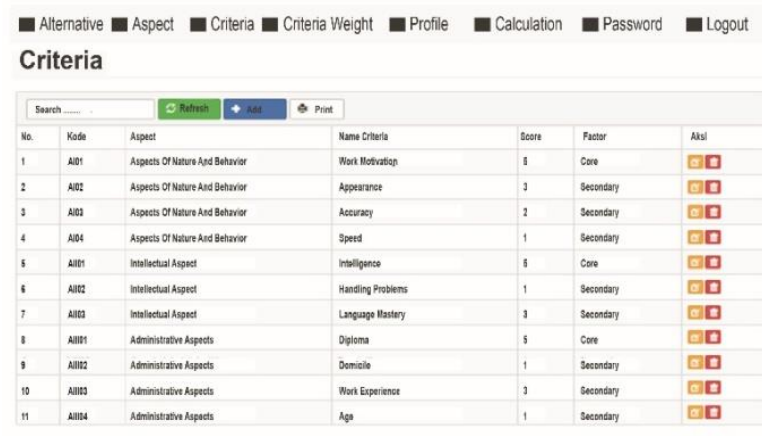

Fig. 9. Criteria Page.

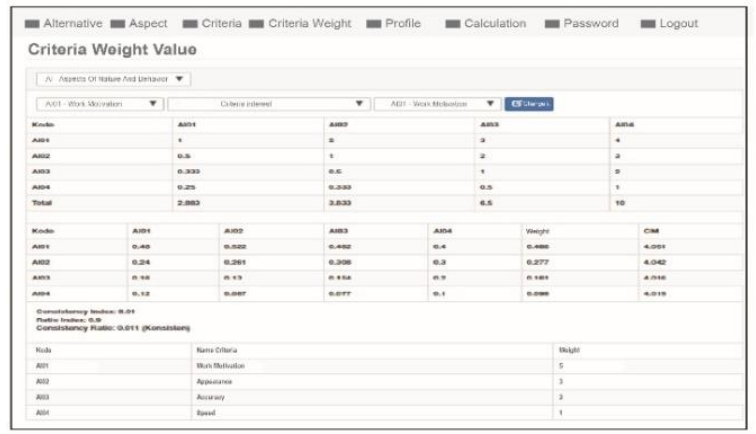

Fig. 10. Criteria Weights Page.

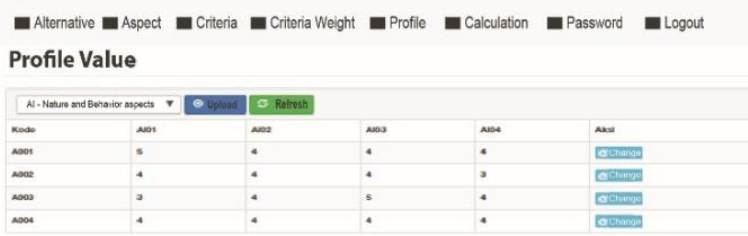

Fig. 11. Profile Page. 


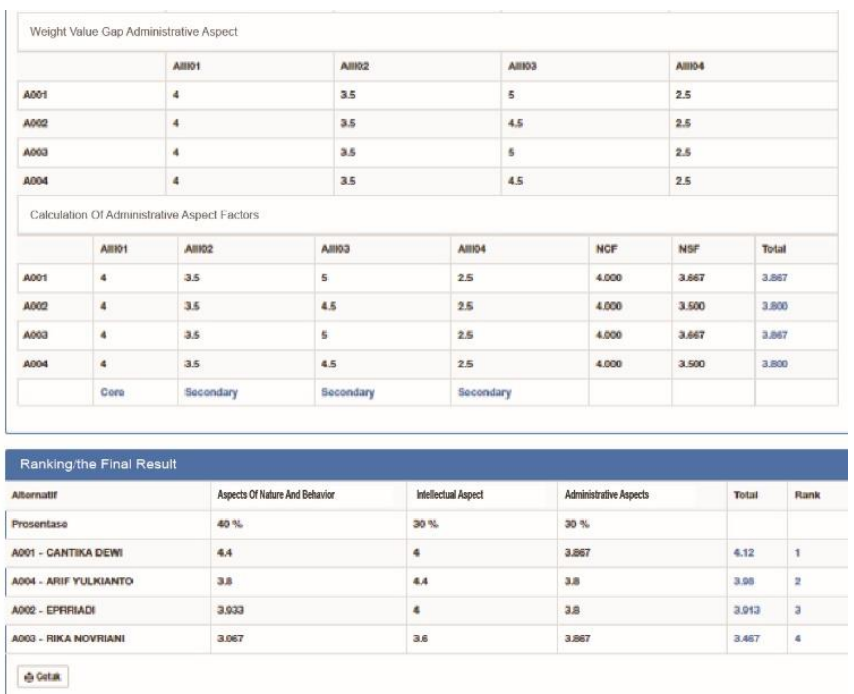

Fig. 12. Calculation Page.

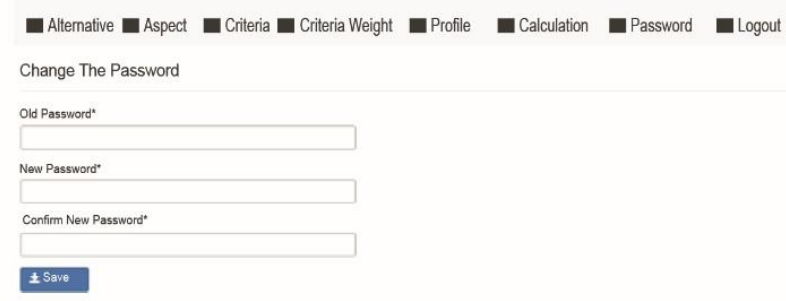

Fig. 13. Password Page.

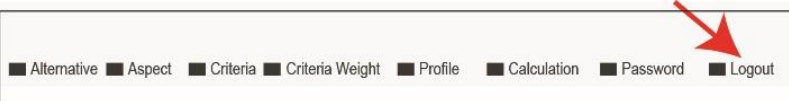

Fig. 14. Log Out Menu.

\section{H. Systems Testing}

This validation test was carried out to assess the design specifications as expected or not according to user requirements, validity testing in this study used User Acceptance Testing (UAT) and Delone and McLean Model while testing the ability of the system was carried out to test the software produced, Black Box Testing.

Black Box Testing, called Behavioral Testing, focuses on the functional requirements of the software. That is, the Black Box Testing technique makes it possible to obtain a set of input conditions that will fully implement all functional requirements for a program.

User Acceptance Testing (UAT), which is a system testing conducted by the user of the system to ensure the system is running well according to user needs.

Delone and McLean Model, namely, Delone and Mclean which states that information quality, system quality and service quality will positively influence use and user satisfaction and subsequently will have a positive effect on net benefits or final results.

Back box testing using questionnaire data on 60 respondents can be seen in Table XXXVII as follows:
TABLE. XXXVII. BLACK BOX TEST TYPE

\begin{tabular}{|c|c|c|c|}
\hline NO & Class test & Test unit & Test result \\
\hline 1 & Login testing & Inputting Username \& Password & Succeed \\
\hline \multirow{4}{*}{2} & \multirow{4}{*}{$\begin{array}{l}\text { Alternative } \\
\text { testing }\end{array}$} & Adding alternative data & \multirow{4}{*}{ Succeed } \\
\hline & & Delete alternative data & \\
\hline & & Change alternative data & \\
\hline & & Save alternative data & \\
\hline \multirow{4}{*}{3} & \multirow{4}{*}{ Aspect testing } & Add criterion data & \multirow{4}{*}{ Succeed } \\
\hline & & Delete criterion data & \\
\hline & & Change criterion data & \\
\hline & & Save criterion data & \\
\hline \multirow{3}{*}{4} & \multirow{3}{*}{$\begin{array}{l}\text { Criterion } \\
\text { testing }\end{array}$} & Input criterion data & \multirow{3}{*}{ Succeed } \\
\hline & & Change criterion data & \\
\hline & & Save criterion data & \\
\hline 5 & $\begin{array}{l}\text { Criterion's } \\
\text { weight testing }\end{array}$ & Change weight comparison & Succeed \\
\hline 6 & $\begin{array}{l}\text { Calculation } \\
\text { process }\end{array}$ & Calculation/ranking & Succeed \\
\hline 7 & $\begin{array}{l}\text { Menu } \\
\text { password }\end{array}$ & Password change & Succeed \\
\hline 8 & Menu logout & Logout from system & Succeed \\
\hline
\end{tabular}

UAT testing from questionnaire results from 10 respondents can be seen on Table XXXVIII.

Testing using Delone and Mclean model using questionnaire from 10 respondents can be seen on Table XXXIX as follows:

The results of the testing using three different types of testing which are Black Box Testing, User Acceptance Testing (UAT) and Delone and McLean Model by giving respondents set of questionnaire yield a satisfying result. Back box testing in the decision support system combination of AHP and Profile Matching can be received and run very well.

TABLE. XXXVIII. CONCLUSION OF USER ACCEPTANCE TESTING (UAT)

\begin{tabular}{|l|l|l|l|l|}
\hline No & Aspects & $\begin{array}{l}\text { Actual } \\
\text { score }\end{array}$ & $\begin{array}{l}\text { Ideal } \\
\text { score }\end{array}$ & $\begin{array}{l}\text { Total } \\
\text { score } \%\end{array}$ \\
\hline 1 & Perceived Ease of Use & 220 & 250 & $88 \%$ \\
\hline 2 & Perceived Usefulness & 219 & 250 & $87,6 \%$ \\
\hline 3 & Attitude Toward Using & 216 & 250 & $86,4 \%$ \\
\hline 4 & Behavioral Intention To Use & 124 & 150 & $82,6 \%$ \\
\hline Total & & 779 & 900 & $86.1 \%$ \\
\hline
\end{tabular}

TABLE. XXXIX. CONCLUSION OF DELONE AND MCLEAN MODEL TESTING

\begin{tabular}{|l|l|l|l|l|}
\hline No & Aspect & $\begin{array}{l}\text { Actual } \\
\text { score }\end{array}$ & $\begin{array}{l}\text { Ideal } \\
\text { score }\end{array}$ & $\begin{array}{l}\text { Total } \\
\text { score \% }\end{array}$ \\
\hline 1 & Information Quality & 210 & 250 & $84 \%$ \\
\hline 2 & System Quality & 213 & 250 & $85.2 \%$ \\
\hline 3 & Service Quality & 130 & 150 & $86.6 \%$ \\
\hline 4 & Use & 86 & 100 & $86 \%$ \\
\hline 5 & User Satisfaction & 87 & 100 & $87 \%$ \\
\hline \multicolumn{2}{|l|}{ Total } & 726 & 850 & $85.7 \%$ \\
\hline
\end{tabular}




\section{CONCLUSIONS AND SugGestions}

\section{A. Conclusions}

Based on the description explained, the conclusions obtained from this paper are as follows:

By using a combination of Analytic Hierarchy Process (AHP) and Profile Matching (PM) methods, the selection process of prospective employees can be carried out well. In the employee selection process a lot of data and the same name can be processed using a database-based system, to avoid data duplication, or file exchange.

Based on system testing, using three different methods of testing resulted that system can be accepted by the company, User Acceptance Testing (UAT) obtained from respondents totalling of 10 people with an ideal score of 900 are given an actual score of 779 or $86.1 \%$, overall the system is acceptable. Delone and McLean Model Test results obtained from 10 respondents with an ideal score of 850 produced an actual score of 726 or $85.7 \%$, overall the quality of this system is running very well. With the results of ranking: A001 - Cantika Dewi $=4.12$, A004-Arif Yulkianto $=3.98$, A002 Eprriadi $=$ 3,913, A003-Rika Novriani = 3,467.

\section{B. Suggestions}

To create a support system for the Analytic Selection Process for Prospective Employees (AHP) and Profile Matching (PM) Methods, better in the implementation phase, it needs support from all parties, both from PT.Prima Grafika or related staff and need to add software testing another to actualize the use of employee selection.

\section{REFERENCES}

[1] M. Azman Maricar ,et al, 2016, Decision Support System of the Employees Acceptance using Analytical Hierarchy Process (AHP) and Multi Factor Evaluation Process (MFEP)International Journal of Engineering and Emerging Technology, Vol. 1, No. 1.

[2] Susilowati, T. et al. 2018. "Using Profile Matching Method to Employee Position Movement." International Journal of Pure and Applied Mathematics 118(7 Special Issue).

[3] Ngurah IG, Partha W, Novenando P, Weking M, Sudarmojo YP. Designing a Decision Support System for the Best Employee Selection Using AHP Method Case Study PT . Z Bali. 2018;3(2).

[4] Moedjiono, et al, 2016, Decision Support Model for User Submission Approval Energy Partners Candidate Using Profile Matching Method and Analytical Hierarchy Process ,Scientific Journal of Informatics Vol. 3, No. 2, ISSN 2407-7658.

[5] (Shiddieq \& Septyan, 2017) Comparative Analysis of Ahp and Saw Methods in Employee Performance Evaluation (Case Study in Pt.
Grafindo Media Pratama Bandung).

[6] Tata, D., Lumban, S., \& Syahrizal, M. (2018). Decision Support System for Selecting Wireless Router using Promethee Method (Case Study: My Republic Medan), 17, 240-244.

[7] ((Sudrajat, 2019) Selection of Outstanding Employees Using the Method Profile Matching.

[8] Heny Pratiwi Decision Support System For Determination Of Employees Perform Use Multi Factor Evaluation Process Method). Journal of Information Systems, September 2014; Vol.5 No.2: p.95-101.

[9] Kristiana, Titin. 2015. Application of Profile Matching For Performance Appraisal Civil Servants (PNS). ISSN: 1978-1946. Jakarta: Nusa Pillar Journal Mandiri Vol. XI, No. September 2, 2015: 161-170.

[10] Shaout, A \& Yousif, M. K, (2014) "Performance Evaluation -Methods and Techniques Survey" :International Journal of Computer and Information Technology (ISSN:2279 - 0764), Volume 03 - Issue 05.

[11] Sina Khanmohammadi And Mandana Rezaeiahari. AHP Based Classification Algorithm Selection For Clinical Decision Support System Development. Procedia Computer Science, 2014; p.328-334.

[12] El, M., El, A., Segers, J., \& Pais, I. 2016. Computers in Human Behavior Technology adoption in employee recruitment: The case of social media in Central and Eastern Europe. Computers in Human Behavior, 57, 240-249. http://doi.org/10.1016/j.chb.2015.12.043.

[13] Suvendu Chanda Nayak and Chitaranjan Tripathy. Deadline Sensitive Lease Scheduling in Cloud Computing Environment Using AHP. Journal of King Saud University - Computer And Information.

[14] Herman Firdaus, Indra, Gunawan Abdillah, Faiza Renaldi. 2016. Decision Support System for Determination of TerGood Employees Using AHP and TOPSIS Methods. National Seminar on Information and Communication Technology 2016 (SENTIKA 2016) Yogyakarta.

[15] Handayani, Rani Irma (2017). Supporting Decision System for Employee Achievement Selection with Profile Matching Method in Pt. Sarana Inti Persada (Sip). Pilar Nusa Mandiri Journal, Volume 13 No.1 March 2017, Number 28-34.

[16] Kristiana, Titin (2015). Application of Profile Matching for Performance Assessment of Civil Servants (PNS). Pilar Nusa Mandiri Journal, Vol.XI No.2 September 2015, Number 161-170.

[17] Fashoto,et al,2018,Development of A Decision Support System on Employee Performance Appraisal Using AHP Model, Department of Computer Science, University of Swaziland Vol 2 No 4, ISSN: 25499610 .

[18] ((Sudrajat, 2019) Selection of Achievement Employees Using the Profile Matching Method.

[19] E Cruz-Cunha, M. M., Silva, J. P., Gonçalves, J. J., Fernandes, J. A., \& Ávila, P. S. (2016). ERP Selection using an AHP-based Decision Support System. Information Resources Management Journal, 29(4), 65-81. doi:10.4018/irmj.2016100105.

[20] Rubayet Karim, and C. L Karmaker, "Machine Selection by AHP and TOPSIS Methods." American Journal of Industrial Engineering, vol. 4, no. 1 (2016): 7-13. doi: 10.12691/ajie-4-1-2.

[21] Xiaohui Liang 2013. "Definisi Profile Matching .Jakarta. 